\title{
Current Account Balance and Export Performances: Evidence Based on New EU Countries*
}

\author{
Željko Bogdan ** \\ Boris Cota** \\ Nataša Erjavec ***
}

\begin{abstract}
In this paper, we investigate whether the differences in the current account balance and export performances for a new EU countries are a result of exchange rate policies. The analysis shows that countries with a flexible exchange rate have better export performances and the current account balance in the pre-crisis period. The obtained results show that movements in the current account balance are mainly driven by domestic variables. In the countries with a flexible exchange rate, real and nominal depreciation affects export positively although the magnitude of these effects is tiny and limited to the crisis period. These results point to a higher significance of non-price competitiveness on export which should be a future research topic.
\end{abstract}

Keywords: current account balance; export; dynamic panel model; effective exchange rate; economic growth

JEL Classification: $\mathrm{C} 33, \mathrm{~F} 32, \mathrm{~F} 41$

\section{Introduction}

Current account determinants and factors of export performances are among the most interesting topics for economists especially in small open economies (such as new EU members) where the effects of export on overall economic activity are emphasized. The importance of export on domestic activity is usually measured by real export growth rates or by the share of export in gross domestic product (export ratio). In basic econometric models, export is usually set as a function of foreign demand

\footnotetext{
* This work has been fully supported by the Croatian Science Foundation under the project: No. IP-092014-5476. The paper is based on the research presented at the 8th Odyssey Conference (Bogdan, Cota, Erjavec, 2016). The authors thank Odyssey participants for useful comments.

** Željko Bogdan, Boris Cota and Nataša Erjavec are at the Faculty of Economics and Business Zagreb, University of Zagreb, Zagreb, Croatia.
} 
and the real effective exchange rate. Given the foreign demand, real depreciation is needed to improve export, which can be achieved via nominal depreciation or via a decrease in relative prices. Real depreciation makes foreign goods and services relatively more expensive and domestic relatively cheaper and promotes export.

In the fixed exchange rate regime real depreciation is possible only by price and cost adjustment. Some new EU countries accepted this regime. However, some economies with a flexible exchange rate in the first stage of transition to EU integration (such as Slovakia, Hungary, the Czech Republic and Slovenia) became the biggest new EU exporters. These facts impose the following research questions: does the nature of the exchange rate regime affect the current account balance and export performances in emerging EU countries? If the answer is positive, does it mean that these differences can be explained by exchange rate policies (and different exchange rate regimes)? This paper aims to give answers to these questions by testing the following hypotheses:

H1: Movements in the current account balance in observed countries are primarily driven by domestic factors;

H2: New EU countries with the flexible exchange rate regime had a higher inclination to export and import in the pre-crisis period and became more engaged in foreign trade with the improved-current account balance. In the crisis period these differences disappear;

H3: Differences in export performances can be attributed to exchange rate policies but effect of non-price competitiveness is more significant;

H4: The flexible exchange rate regime via nominal depreciation helped to improve export performances in new EU members in the crisis period.

Completion of EU accession of some countries (Romania and Bulgaria in 2007, Croatia in 2013 and others in 2004) also contributed to higher export, mainly as a consequence of the fact that "old EU countries" are their main trading partners. However, in the case of Croatia, these positive aspects are limited by the debt crisis and economic stagnation in Europe.

The results of our paper indicate that all the hypotheses can be accepted. It is confirmed that movements in the current account balance are driven by domestic economic indicators. Unlike import ratio which does not significantly differ across countries, these countries which adopted the flexible exchange rate have a higher export ratio, which is related more to non-price competitiveness than to the exchange rate policies. Furthermore, effects of real depreciation, which are limited to crisis period, are primarily caused by changes in the nominal exchange rate. Our empirical analysis confirms importance to promote export using the exchange rate.

The paper is organized as follows. The next section reviews the literature and discusses recent developments regarding determinants of the current account balance and export. Section 3 describes the data sets and variables used in the study. The methodology and the empirical model are discussed in section 4 . The obtained 
results are presented in section 5. Finally, section 6 provides concluding remarks, limitations of research and guidelines to future research.

\section{Literature Review}

The literature on current account balances and export is extensive. Large current account imbalances can be an indicator of macroeconomic and financial risks. A common monetary policy in Eurozone influence current account balancing mechanisms within their members. There are various factors which could cause a current account deficit and export performance.

Harkmann and Staehr (2012), Kang and Shambaugh (2013), Cesaroni and DeSantis (2015) shows that higher domestic demand deteriorates current account balance via growth of imports and it is usually financed by capital inflow. Gehringer (2013) confirms the role of the construction sector in deterioration of the current account balance which is especially shown in the case of the Mediterranean EU countries and Ireland. The influence of domestic demand can also be related to export performances keep in mind that higher foreign demand or real depreciation will not increase export when domestic firms are more oriented towards the domestic market. Esteves and Rua (2015) confirm a negative relationship between domestic demand and export in the short run.

Export performances can be related to price or non-price competitiveness. Kang and Shambaugh (2013), confirm the importance of non-price competitiveness finding the positive relationship between export and real appreciation in the new EU members. However, Blanchard, Dell'Ariccia and Mauro (2010) conclude that a large appreciation may squeeze the domestic tradable sector and make it difficult to achieve desired growth if and when the exchange rate decreases.

During recent economic stagnation, some of the papers emphasize unit labor costs (ULC) as the factors of competitiveness in the Eurozone periphery and underline the importance of structural reforms. Zemanek, Belke and Schnabl (2010) state that in the Eurozone periphery, the reduction of ULC is needed in order to improve export and reduce intro-euro area balances.

However, recent research does not relate competitiveness with ULC. Felipe and Kumar (2014) point out that ULC on the national level is not an appropriate measure of competitiveness (especially if a country is compared to Germany). They find the reasons for weak export performances of the Eurozone periphery lies in the production structure rather than in ULC. Gaullier and Vicard (2013) emphasize that the current account dynamics in the Eurozone is highly correlated with ULC and imports but the same is not confirmed for export. They argue that ULC is not the source of the demand shocks and is not associated with losses in export competitiveness. Kang and Shambaugh (2013) show that export in the Mediterranean and Baltic countries grows regard- 
less of higher ULC, but capital inflow raises ULC in the non-tradable sector and boosts imports. Blanchard (2007) points out that policies engaged in reducing the ULC to improve export competitiveness in the Eurozone periphery would be painful and economically controversial. Namely, effective ULC reduction would not yield the desired results when ULC decreases in some countries competing on the same export market.

\section{Data Description}

Current account determinants and export performances, as well as the exchange rate policies, are already noted as important factors for small open economies such as new EU members. In empirical literature, exchange rate regimes are classified into three categories, i.e. peg, float and intermediate regimes ${ }^{1}$.

In our analysis, the countries which follow hard and soft pegs are included among fixed exchange rate countries (labeled fixed) since the changes of the nominal effective exchange rate (labeled NEER) are small. This set of countries includes Bulgaria, Estonia, Latvia, Lithuania and Croatia ${ }^{2}$. The rest of the countries with float and intermediate regimes (i.e. Poland, Romania, Slovakia, Hungary, the Czech Republic and Slovenia) are included among the flexible exchange rate group (labeled flexible).

However, some specific characteristics of exchange rate regimes should be emphasized. For example, average NEER in the flexible group is affected by substantial depreciations of NEER in Romania (to 2004), oscillations in Poland, slower depreciations in Slovenia and Hungary and appreciations in the Czech Republic and Slovakia during a part of the observed period. Also, Slovenia (from 2004) and Slovakia (from 2005) entered into the ERM II mechanism before the final adoption of euro which de facto turned them into the fixed exchange rate regime. This would justify the inclusion of these economies into the fixed group once the euro adoption process has begun, ignoring the fact that the higher inclination to export is achieved during the regime of the flexible exchange rate. Furthermore, it would has an effect on a number of observations in both groups as well as artificially increase average values of the export-GDP ratio in economies with a fixed exchange rate. Hence we treat Slovakia and Slovenia as economies with a flexible exchange rate during the whole period. Among analyzed countries Poland, Croatia and Romania have the weakest exporting performances, but Romania and Poland also can be considered as countries with the large domestic market which usually implies relatively weak export propensity.

Following the results of researchers presented in the previous section, we are interested whether there are some differences in the current account balance and export performances among new EU members regarding the exchange rate regimes. In our model, the real GDP growth rate (GROWTH), the output gap (YGAP), the real effective exchange rate (REER) and the budget balance (BB) are taken as key determinants of the current account $(\mathrm{CAB})^{3}$. 
Standard export function usually includes foreign demand and effective exchange rate (nominal or real) where increase stands for appreciation and vice versa. In our model, the foreign demand is proxied by real GDP growth in EU-15 (GROWTH_EU15) ${ }^{4}$.

The analysis is focused on the period between 1999 (adoption of euro) and 2014, which covers a pre-crisis period (1999-2008) and slump (2009-2014). Using yearly data we avoid the potential problem of strong seasonality in some data (such as exchange rates). A complete list of variables is presented in Tables 1 and 2 in Appendix.

Descriptive statistics for new EU members regarding exchange rate regime and economic activity (1999-2014) are given in Table 3 in Appendix. Performed statistical test confirm that in the pre-crisis period the average values of CAB, EXPORT, NEER and inflation (INFLATION) are significantly higher in countries with a flexible exchange rate. Furthermore, in these countries, the average values of GROWTH, YGAP, REER and BB are significantly smaller. The majority of these differences completely disappear in the crisis period (with exception of REER and BB). Annual averages of variables for both groups are also presented in Figure 1 in Appendix.

Negative average values of $\mathrm{CAB}$ indicate that investments exceed saving. However, higher average current account deficit financed mainly by debt capital inflow in the pre-crisis period in countries using fixed exchange rate regime implies stronger relative contribution of domestic demand on economic activity and upward pressure on inflation. Domestic demand decreases in both groups in the crisis period improving current account balance via import decline. In countries with the flexible exchange rate, a decrease in domestic demand along with increasing imports ratio show the export orientation of these countries.

The analysis of export performances requires some indicators of competitiveness. The basic (price) competitiveness indicator is the real effective exchange rate (REER) which depends on the nominal effective exchange rate (NEER) and relative prices. NEER and INFLATION are "domestic" determinants of REER. When the nominal exchange rate is fixed, changes in the price levels are the main determinant of the real effective exchange rate (REER) ${ }^{5}$.

According to obtained results, it can be concluded, that the debt capital inflow stimulated domestic demand in countries with a fixed exchange rate, resulting in inflation growth. Since the nominal exchange rate is de facto fixed, it appreciates REER and deteriorates export performances. However, real appreciation can be amplified via nominal appreciation when a country follows a flexible exchange rate regime. In the crisis period, it mainly decreases, amplifying real depreciation which can stimulate export. In that case, we can expect a positive relationship between EXPORT and REER in the pre-crisis and a negative relationship in the crisis period.

In our econometric model, differences among exchange rate regimes are captured by a dummy variable DFLEX which takes the value of 1 if the exchange rate was flexible in the first stage of transition and 0 otherwise. Effects of different exchange rate regimes on CAB and EXPORT are captured by the slope dummy REERFLEX which captures different effects of changes in REER in countries with a flexible exchange rate. 
The difference in the effect of changes in effective exchange rates on the dependent variable between the group of countries can not be attributed only to different exchange rate regimes. Some other factors, such as business climate, the complexity of goods, FDI in the industrial sector, financial conditions, could also affect these differences.

\section{Methodology}

In the empirical part, models for the current account balance and export are estimated separately. The first of them (with $\mathrm{CAB}$ as the dependent variable) takes the following form:

$$
\begin{aligned}
\mathrm{CAB}_{\mathrm{it}} & =\gamma \mathrm{CAB}_{\mathrm{it}-1}+\beta_{1} \mathrm{GROWTH}_{\mathrm{it}}+\beta_{2} \mathrm{YGAP}_{\mathrm{it}}+\beta_{3} \mathrm{BB}_{\mathrm{it}}+\beta_{4} \text { REER }_{\mathrm{it}} \\
& +\beta_{5} \text { REERFLEX }_{\mathrm{it}}+\beta_{6} \mathrm{GROWTH}_{-} \mathrm{GU}_{1}{ }_{\mathrm{it}}+\mu_{\mathrm{i}}+\varepsilon_{\mathrm{it}}
\end{aligned}
$$

where $\mu_{\mathrm{i}}$ are the (unobserved) individual effects, and $\varepsilon_{\mathrm{it}}$ the error term $(i=1 \ldots N$; $i=1 \ldots T)$. Regressor variables have already been explained in the previous paragraph (data description). ${ }^{6}$

The basic form of the second model (with EXPORT as the dependent variable) is:

$$
\begin{gathered}
\mathrm{EXPORT}_{\mathrm{it}}=\delta \mathrm{SEXPORT}_{\mathrm{it}-1}+\alpha_{1} \mathrm{REER}_{\mathrm{it}}+\alpha_{2} \mathrm{GROWTH}_{-} \mathrm{EU} 15_{\mathrm{it}} \\
+\alpha D U M M Y_{\mathrm{it}}+\mu_{\mathrm{i}}{ }^{\prime}+\varepsilon_{\mathrm{it}}{ }^{\prime},
\end{gathered}
$$

where $\mu_{\mathrm{i}}$ ' are the (unobserved) individual effects, and $\varepsilon_{\mathrm{it}}{ }^{\prime}$ the error term $(i=1 \ldots N$; $i=1 \ldots T)$.

Model (2) is a standard export function where differences regarding exchange rate regimes, country groups and periods are captured by several dummy variables comprised in the matrix $D U M M Y$ with a vector of associated parameters $\alpha$.

Two forms of the model (2) are estimated. The first one includes a dummy variable REERFLEX (that captures differences in the effects of REER on EXPORT regarding the exchange rate regime), CRISIS (a dummy variable to account for higher export in the crisis period) and several time-dummy variables. In the second model, dummy variable REERFLEX is replaced by dummy that captures changes in REER during the crisis period in countries with the flexible exchange regime (REERFLEXCRISIS).

To answer whether changes in the real effective exchange rate affect EXPORT via changes in the nominal effective exchange rate, in the third model REER is replaced by NEER:

$$
\begin{aligned}
\text { EXPORT }_{\mathrm{it}}=\mu \mathrm{EXPORT}_{\mathrm{it}-1}+\rho_{1} \mathrm{NEER}_{\mathrm{it}}+\alpha_{2} \mathrm{GROWTH}_{-} \mathrm{EU} 15_{\mathrm{it}} \\
+\rho \mathrm{NMMY}_{\mathrm{it}}+\mu_{\mathrm{i}}^{*}+\varepsilon_{\mathrm{it}}^{*},
\end{aligned}
$$


where $\mu_{i}{ }^{\prime}$ are the (unobserved) individual effects, and $\varepsilon_{\text {it }}{ }^{\prime}$ the error term $(i=1 \ldots N$; $i=1 \ldots T)$. A matrix DUMMY* includes the same set of dummy variables as in (2) except that REERFLEXCRISIS is replaced by NEERFLEXCRISIS.

Dependent variables in all models are affected by its lagged values making dynamic panel estimation as a logical solution. Short time and spatial panel dimensions $(\mathrm{N}=11, \mathrm{~T}=15)$ forced us to use corrected least square dummy variables (LSDVC) proposed by Kiviet (1995), which proved to be the most preferable estimator in small panel data like ours (Judson, Owen (1999), Bruno (2005), Buddelmeyer et. al (2008)). As it is well known, the standard LSDV estimator in dynamic panel analysis has poor properties (bias, inconsistency) but has a small variance. The idea of LSDVC estimation is to correct the bias of initial LSDV estimator by using some consistent estimator such as Arellano-Bond (AB), Blundell-Bond (BB) or Anderson-Hsiao (AH) as proposed by Bruno (2005). Hence LSDVC estimates will differ and depend on estimates chosen to correct initial bias in LSDV estimator. In the empirical results we present all of them labelled as; LSDVC-1 (based on AB), LSDVC-2 (based on BB) and LSDVC-3 (based on AH). However, initial estimates used in correction must be valid which is tested for LSDVC-1 and LSDVC-2 by Arellano-Bond and Sargan tests; i.e. a test for autocorrelation of the residuals and a test of the validity of instruments.

Expected signs and a complete list of variables used in the analysis are provided in Tables 1 and 2 in Appendix.

\section{Empirical Results}

Estimates of all models are given in Tables 4 to 7 in Appendix. As can be seen, all LSDVC estimates are almost identical, regardless of the estimator chosen to initialize the bias correction and in line with our expectations.

The estimation results of the model (1) for the current account balance (Table 4) did not confirm the significance of BB, REER and REERFLEX implying that differences in $\mathrm{CAB}$ are not related to the exchange rate regime.

Insignificance and negative sign of variable GROWTH_EU15 which captures foreign demand imply that current account balance is primarily affected by domestic factors, such as variable GROWTH. Moreover, variable YGAP is not significant indicating that the current account development is not affected by this cyclical component.

The estimation results of the model (2) for export (Table 5) show that the variable GROWTH_EU15 is significant. This is the expected result since the EU-15 countries are the most important trade partners of analyzed countries. Different exchange rate regimes have a significant impact on export performances. Variable REERFLEX has a negative sign, suggesting that flexible exchange rate improves export.

The significance of dummy variable CRISIS points out that countries react to crises with higher export. Regarding variables indicating the real exchange rate (Table 
6), they are not significant with the exception of REERFLEXCRISIS implying that the positive effects of the real exchange rate have been achieved during the crisis period. The changes in REER in the crisis period are primarily driven by movements in NEER when the exchange rate is flexible. In such case, NEERFLEXCRISIS must be significant in the model (3). This is confirmed by the results presented in Table 7 although nominal exchange rate (NEER) is insignificant.

\section{Conclusion}

This paper aims to investigate whether the differences in the current account balance and export performances in new EU members are a result of exchange rate policies. The answer to this question is obtained by testing four hypotheses.

In favor of the first hypothesis, we find that movements in the current account balance in observed economies are primarily driven by domestic factors. Regarding the second hypothesis our results show that in the pre-crisis period, economies with a flexible exchange rate had better performance in current account balances and export. Differences are also visible in the export structure since the countries with fixed exchange rate are relatively more engaged in service export. Differences in overall export diminished in the crisis period as a consequence of a relatively higher increase in export in countries with the fixed exchange rate. Since the differences in import ratios have not been confirmed either in the pre-crisis or during the crisis period, we conclude that countries with flexible exchange rate are more engaged in foreign trade in the pre-crisis period through higher export. Regarding the third hypothesis, estimation results suggest that export in new EU countries are affected by the growth in the EU-15 countries as their main trading partners. The results also indicate that real depreciation stimulates export, though the effects are limited to the crisis period. The obtained results suggest that non-price factors are more important than price factors regarding competitiveness. However, this does not imply an irrelevant role of the nominal exchange rate since nominal depreciation can stimulate export or relax deterioration of price competitiveness. As for the fourth hypothesis, our results indicate that exchange rate policies could be useful in boosting export.

The obtained results open up some additional questions regarding the importance of non-price factors on export performances and labor costs changes. Assessing these questions in the future research would be fruitful.

The main limitation of this research is the fact that we did not take into account EU accession for all observed countries (in 2004, 2007 and 2013) and euro adoption in the majority of them (after 2007) which has allowed access to single EU market and has eliminated exchange rate risk. 


\section{APPENDIX}

Figure 1: Annual averages of variables used in analysis
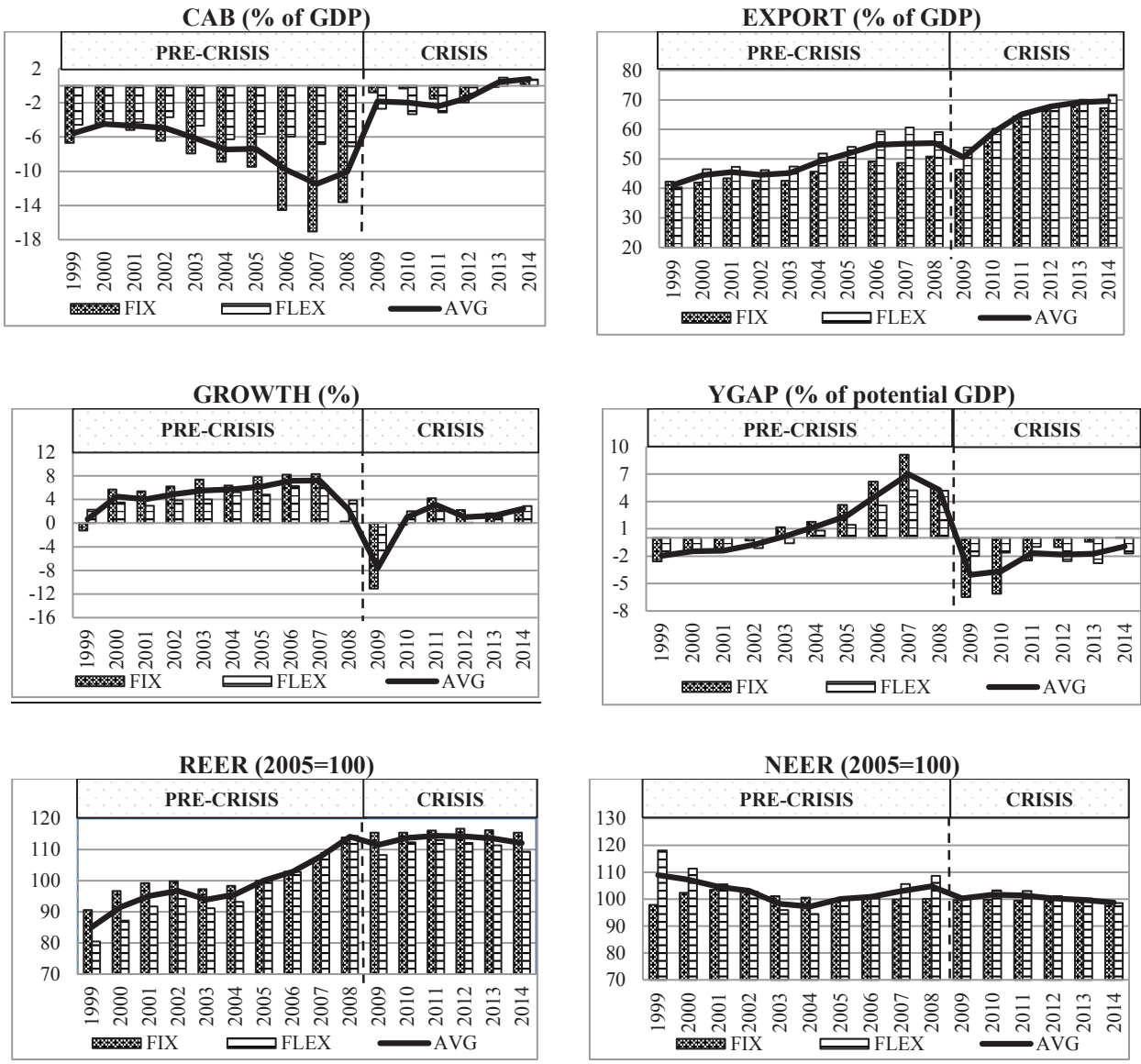

\section{BB (\% of GDP)}

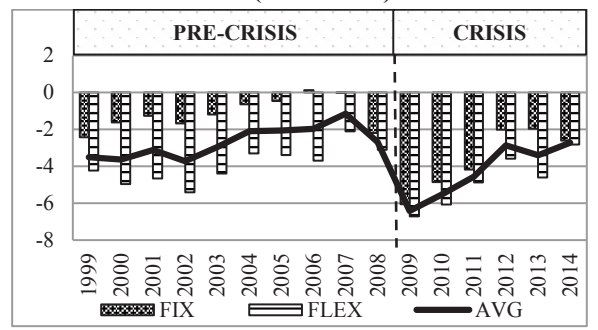

NOTE: AVG, FIX and FLEX denote annual averages for all countries, for countries with fixed exchange rate and for countries with flexible exchange rate, respectively. Slovakia and Slovenia are included in a group with flexible exchange rate regime.

Source: AMECO (for CAB and YGAP), Eurostat (for the rest of variables). 


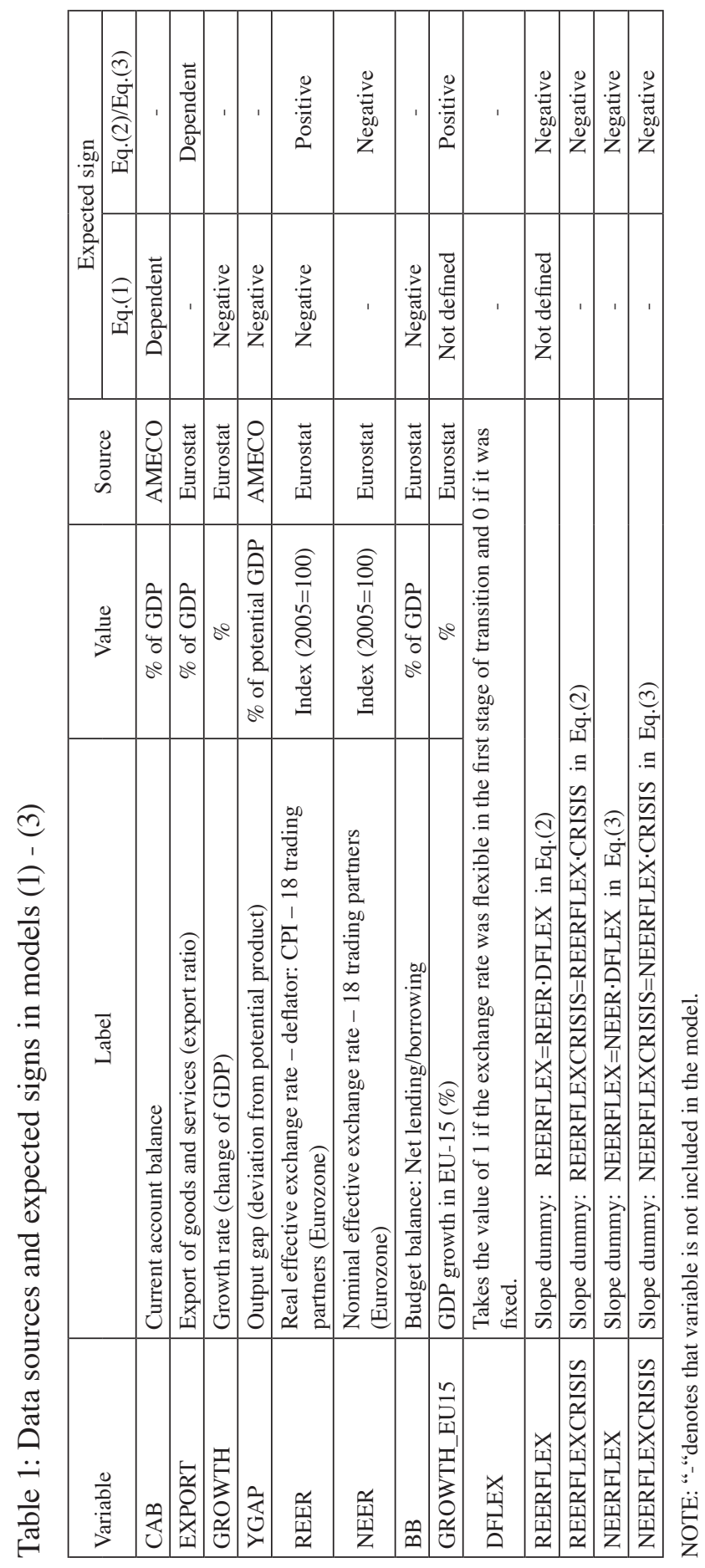




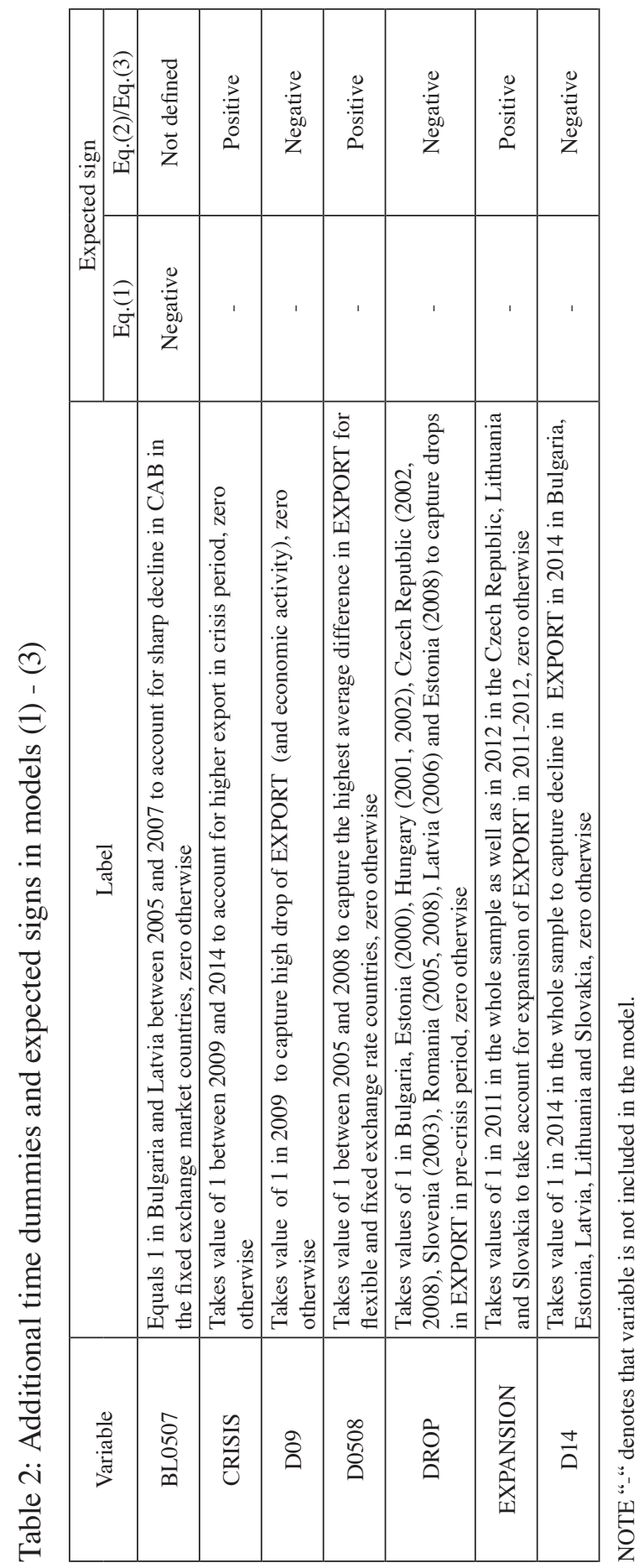




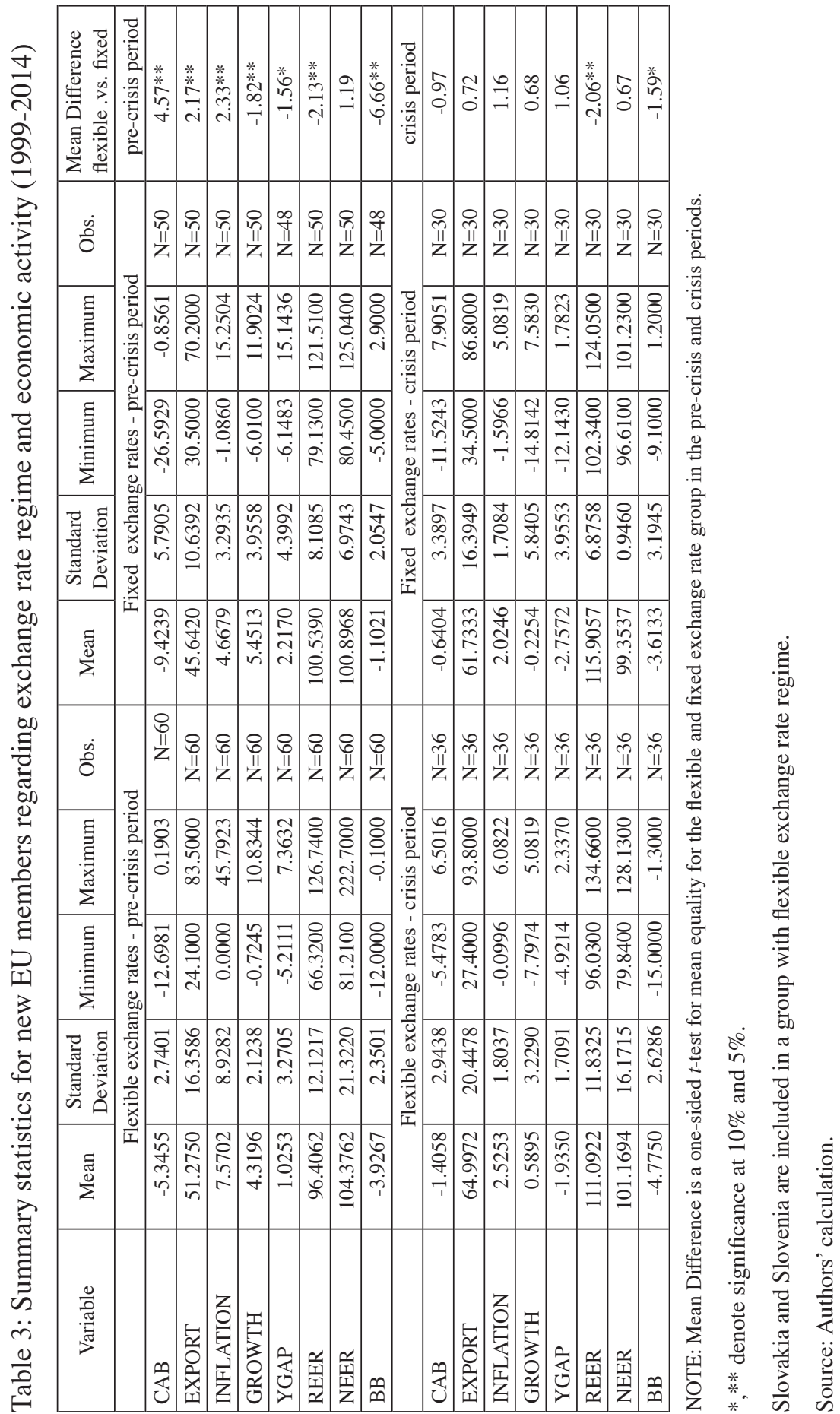


Table 4: Estimation of model (1)

\begin{tabular}{|l|c|c|c|}
\hline \multirow{2}{*}{ L.CAB } & \multicolumn{2}{|c|}{ Model (1a-1): Dependent variable CAB } \\
\cline { 2 - 4 } & LSDVC-1 & LSDVC-2 & LSDVC-3 \\
\hline GROWTH & 0.70 & 0.70 & 0.71 \\
& $(0.05)^{* * *}$ & $(0.05)^{* * *}$ & $(0.05)^{* * *}$ \\
\hline YGAP & -0.43 & -0.43 & $(0.43746$ \\
& $(0.09)^{* * *}$ & $(0.09)^{* * *}$ & -0.11 \\
\hline BB & -0.12 & -0.12 & $(0.08)$ \\
\hline REER & $(0.08)$ & $(0.08)$ & 0.08 \\
& 0.07 & 0.07 & $(0.10)$ \\
\hline REERFLEX & $(0.09)$ & $(0.09)$ & 0.01 \\
& 0.02 & 0.03 & $-0.04)$ \\
\hline GROWTH_EU15 & $(0.04)$ & -0.04 & $(0.05)$ \\
\hline BL0507 & -0.02 & $(0.04)$ & -0.15 \\
& $(0.04)$ & -0.15 & $(0.15)$ \\
\hline Observations & -0.15 & $(0.14)$ & -4.69 \\
Number of groups & $(0.14)$ & -4.72 & $(1.17)^{* * *}$ \\
\hline
\end{tabular}

NOTE: Standard errors in parentheses. $* * *, * * *$ denote significance at $10 \%, 5 \%$ and $1 \%$ significance level.

Initial LSDVC estimates are as follows: LSDVC-1 (Arellano - Bond); LSDVC-2 (Blundell-Bond) and LSDVC-3 Anderson-Hsiao. Estimation is performed using Stata routine xtlsdvc, (Bruno, 2005).

Source: Authors' calculation.

Table 5: Estimation of model (2) with dummy variables REERFLEX and CRISIS

\begin{tabular}{|l|c|c|c|}
\hline \multirow{2}{*}{ L.EXPORT } & \multicolumn{2}{|c|}{ Dependent variable EXPORT } \\
\cline { 2 - 4 } & LSDVC-1 & LSDVC-2 & LSDVC-3 \\
\hline REER & 0.82 & 0.88 & 0.83 \\
& $(0.04)^{* * *}$ & $(0.04)^{* * *}$ & $0.05)^{* * *}$ \\
\hline CRISIS & 0.15 & 0.15 & 0.15 \\
& $(0.05)^{* * *}$ & $(0.06)^{* * *}$ & $4.98)^{* *}$ \\
\hline REERFLEX & 4.80 & 4.49 & $(1.31)^{* * *}$ \\
\hline D09 & $(1.04)^{* * *}$ & $(1.10)^{* * *}$ & -0.15 \\
& $(0.16$ & -0.18 & $(0.07)^{* *}$ \\
\hline D0508 & -5.00 & $(0.05)^{* * *}$ & -5.02 \\
& $(1.69)^{* * *}$ & -4.24 & $(2.13)^{* *}$ \\
\hline GROWTH_EU15 & 0.96 & $(1.83)^{* *}$ & 0.87 \\
& $(0.79)$ & 0.79 & $(0.99)$ \\
\hline DROP & 0.90 & $(0.88)$ & 0.91 \\
& $(0.25)^{* * *}$ & $(0.27)^{* * *}$ & $-51)^{* * *}$ \\
\hline D14 & -5.03 & -5.10 & $(1.25)^{* * *}$ \\
\hline EXPANSION & $(0.98)^{* * *}$ & $(1.13)^{* * *}$ & -4.95 \\
& $(1.63)^{* * *}$ & -5.48 & $(2.06)^{* *}$ \\
\hline Observations & 1.81 & $(1.82)^{* * *}$ & 1.87 \\
Number of groups & $(0.95)^{*}$ & 1.88 & $(1.20)$ \\
\hline
\end{tabular}

NOTE: Standard errors in parentheses. $*$,***** denote significance at $10 \%, 5 \%$ and $1 \%$ significance level.

Initial LSDVC estimates are as follows: LSDVC-1 (Arellano - Bond); LSDVC-2 (Blundell-Bond) and LSDVC-3 Anderson-Hsiao. Estimation is performed using Stata routine xtlsdvc, (Bruno, 2005).

Source: Authors' calculation. 
Table 6: Estimation of model (2) with dummy variable REERFLEXCRISIS

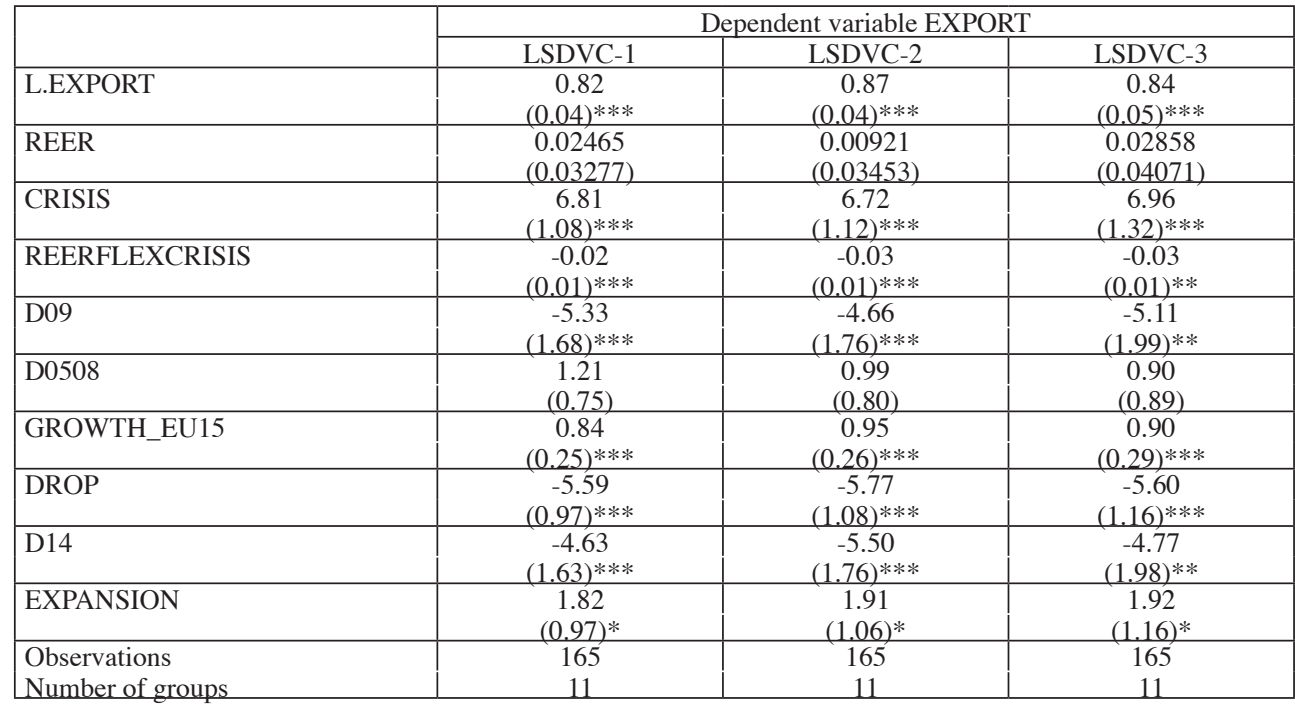

NOTE: Standard errors in parentheses. *,***** denote significance at $10 \%, 5 \%$ and $1 \%$ significance level.

Initial LSDVC estimates are as follows: LSDVC-1 (Arellano - Bond); LSDVC-2 (Blundell-Bond) and LSDVC-3 Anderson-Hsiao. Estimation is performed using Stata routine xtlsdvc, (Bruno, 2005).

Source: Authors' calculation.

Table 7: Estimation of model (3) with dummy variable NEERFLEXCRISIS

\begin{tabular}{|c|c|c|c|}
\hline & \multicolumn{3}{|c|}{ Dependent variable EXPORT } \\
\hline & LSDVC-1 & LSDVC-2 & LSDVC-3 \\
\hline L.EXPORT & $\begin{array}{c}0.82 \\
(0.04) * * *\end{array}$ & $\begin{array}{c}0.87 \\
(0.04) * * *\end{array}$ & $\begin{array}{c}0.83 \\
(0.05) * * *\end{array}$ \\
\hline NEER & $\begin{array}{c}0.01527 \\
(0.02422)\end{array}$ & $\begin{array}{c}0.00306 \\
(0.02557)\end{array}$ & $\begin{array}{c}0.01881 \\
(0.02740)\end{array}$ \\
\hline CRISIS & $\begin{array}{c}7.16 \\
(1.05) * * *\end{array}$ & $\begin{array}{c}6.77 \\
(1.05) * * *\end{array}$ & $\begin{array}{c}7.24 \\
(1.20)^{* * *}\end{array}$ \\
\hline NEERFLEXCRISIS & $\begin{array}{c}-0.02 \\
(0.01)^{* * *}\end{array}$ & $\begin{array}{c}-0.03 \\
(0.01) * * *\end{array}$ & $\begin{array}{c}-0.03 \\
(0.01) * *\end{array}$ \\
\hline D09 & $\begin{array}{c}-5.55 \\
(1.71)^{* * *}\end{array}$ & $\begin{array}{c}-4.66 \\
(1.80)^{* * * *}\end{array}$ & $\begin{array}{c}-5.40 \\
(1.92)^{* * *}\end{array}$ \\
\hline D0508 & $\begin{array}{c}1.49 \\
(0.68)^{* *}\end{array}$ & $\begin{array}{c}1.09 \\
(0.71) \\
\end{array}$ & $\begin{array}{c}1.35 \\
(0.77)^{*}\end{array}$ \\
\hline GROWTH_EU15 & $\begin{array}{c}0.80 \\
(0.25) * * *\end{array}$ & $\begin{array}{c}0.94 \\
(0.26) * * * \\
\end{array}$ & $\begin{array}{c}0.83 \\
(0.28) * * *\end{array}$ \\
\hline DROP & $\begin{array}{c}-5.53 \\
(0.98) * * *\end{array}$ & $\begin{array}{c}-5.73 \\
(1.09) * * *\end{array}$ & $\begin{array}{c}-5.52 \\
(1.10) * * *\end{array}$ \\
\hline D14 & $\begin{array}{c}-4.48 \\
(1.62) * * *\end{array}$ & $\begin{array}{c}-5.39 \\
(1.75) * * *\end{array}$ & $\begin{array}{c}-4.55 \\
(1.85) * *\end{array}$ \\
\hline EXPANSION & $\begin{array}{c}1.88 \\
(0.96) * *\end{array}$ & $\begin{array}{c}1.97 \\
(1.06) *\end{array}$ & $\begin{array}{c}1.96 \\
(1.08) *\end{array}$ \\
\hline $\begin{array}{l}\text { Observations } \\
\text { Number of groups }\end{array}$ & $\begin{array}{c}165 \\
11\end{array}$ & $\begin{array}{c}165 \\
11\end{array}$ & $\begin{array}{c}165 \\
11\end{array}$ \\
\hline
\end{tabular}

NOTE: Standard errors in parentheses. ****** denote significance at 10\%, 5\% and 1\% significance level.

Initial LSDVC estimates are as follows: LSDVC-1 (Arellano - Bond); LSDVC-2 (Blundell-Bond) and LSDVC-3 Anderson-Hsiao. Estimation is performed using Stata routine xtlsdvc, (Bruno, 2005).

Source: Authors' calculation. 


\section{NOTES}

${ }^{1}$ The float regime consists of an independent float having a market-determined exchange rate, an independent monetary policy and a managed float with no pre-announced path for the exchange rate. Intermediate regimes include the exchange rate with a crawling peg, crawling bands and a pegged exchange rate within horizontal bands at least $\pm 1 \%$ (Markiewicz, 2006: pp. 486). Pegged regimes can be soft (a fixed peg arrangement within a band of more than $\pm 1 \%$ ) and hard (currency board) (Markiewicz, 2006: pp. 486).

${ }^{2}$ Officially Croatia does not have fixed exchange rate, but the exchange rate stability requirement justifies its inclusion into economies with a fixed exchange rate.

${ }^{3}$ Since YGAP measures the percentage deviation of the actual from the potential GDP, it means that the output gap diminishes if YGAP $<0$ or increases if YGAP $>0$. Similarly "a decrease in BB" denotes a higher budget deficit when $\mathrm{BB}<0$ or lesser surplus when $\mathrm{BB}>0$.

${ }^{4}$ The EU15 comprised the following 15 countries: Austria, Belgium, Denmark, Finland, France, Germany, Greece, Ireland, Italy, Luxembourg, Netherlands, Portugal, Spain, Sweden, United Kingdom.

${ }^{5}$ The average value of REER shows that both groups of countries are faced with real appreciation in the pre-crisis period but differences among them disappear between 2004 and 2008. However, the average REER prior to 2004 and after 2008 in countries with a flexible exchange rate is smaller (Figure 1). Real appreciation was the slowest in Slovenia during the whole period - a real effective exchange rate is maintained stable during the whole period. Slovenian exchange rate policy promoted export successfully especially prior to 2001 .

${ }^{6}$ To obtain model adequacy we experimented with various dummy variables. As it turns out, a dummy variable BL0507 proved to be significant and is additionally included in the model. It captures deterioration of current account balance in Bulgaria and Latvia between 2005 and 2007 with the expected negative sign.

\section{REFERENCES}

Blanchard, O. (2007). Adjustment within the euro. The difficult case of Portugal. Portuguese Economic Journal, Vol. 6, no. 1, 1-12.

Blanchard, O., Dell'Ariccia, G., Mauro, P. (2010). Rethinking Macroeconomic Policy. IMF Staff Position Note, no. 03, 1-19.

Bogdan, Ž., Cota, B., Erjavec, N. (2016). Current Account Balance and Export Performances in New EU Countries - Does Exchange Rate Regime Matter. In $8^{\text {th }}$ International Conference Proceedings: "An Enterprise Odyssey: Saving the Sinking Ship Through Human Capital, 8-11 June 2016, Zagreb, Croatia: Faculty of Economics, 366-380.

Bruno, G. S. (2005). Estimation and inference in dynamic unbalanced panel-data models with a small number of individuals. Stata Journal, Vol. 5, no.4, 473-500.

Buddelmeyer, H., Jensen, P., Oğuzoğlu, U., Webster, E. (2008). Fixed Effects Bias in Panel Data Estimators. IZA Dicussion Paper, no. 3487, 1-7.

Cesaroni, T., DeSantis, R. (2015). Current Account "Core Periphery Dualism" in the EMU. CEPS Working Document, no. 406, 1-30.

Esteves, P. S., Rua, A. (2015). Is there are role for domestic demand pressure on export performance? Empirical Economics, Vol. 49, no.4, 1173-1189.

Felipe, J., Kumar, U. (2014). Unit labor costs in the Eurozone: the competitiveness debate again. Review of Keynesian Economics, Vol. 2, no.4, 490-507. 
Gaullier, G., Vicard, V. (2013). The Signatures of Euroarea Imbalances: Export Performance and the Composition of ULC Growth. Compnet Policy Brief, no. 02, 1-15.

Gehringer, A. (2013). Another Look at the determinants of current account imbalances in the European Union: An empirical assessment. FIW Working Paper, no. 105, 1-29.

Harkmann, K., Staehr, K. (2012). Current Account Balances in Central and Eastern Europe: Heterogeneity, Persistence and Driving Factors. Retrieved December 10, 2015, from http://ies.fsv.cuni. cz/default/file/get/id/20935.

Judson, R., Owen, A. (1999). Estimating dynamic panel data models: a guide for macroeconomists. Economic letters, Vol. 65, no.1, 9-15.

Kang, J. S., Shambaugh, J. (2013). The Evolution of Current Account Deficit in the Euro Area Periphery and the Baltics; Many Paths to the Same Endpoint. IMF Working Paper, no. 169, 1-22.

Kiviet, J. (1995). On bias, inconsistency, and efficiency of various estimators in dynamic panel data models. Journal of Econometrics, Vol. 68, no.1, 53-78.

Markiewicz, A. (2006). Choice of exchange rate regime in transition economies: An empirical analysis. Journal of Comparative Economics, 41 (3), 484 - 498.

Zemanek, H., Belke, A., Schnabl, G. (2010). Current Account Balances and Structural Adjustment in the Euro Area. International Economics and Economic Policy, Vol.7, no.1, 83-127. 